\title{
Acetyl-salicylic acid impairs insulin-mediated glucose utilization and reduces insulin clearance in healthy and non-insulin-dependent diabetic man
}

\author{
P. R. Bratusch-Marrain, H.Vierhapper, M. Komjati and W. K. Waldhäusl \\ Division of Clinical Endocrinology and Diabetes Mellitus, I. Medizinische Universitätsklinik, Vienna, Austria
}

\begin{abstract}
Summary. The effect of acetyl-salicylic acid (ASA, $3 \mathrm{~g}$ per day for 3 days) on glucose utilization and insulin secretion was studied in healthy volunteers and Type 2 diabetic patients using the hyperglycaemic and euglycaemic insulin clamp technique. When in healthy subjects arterial plasma glucose was acutely raised and maintained at $+7 \mathrm{mmol} / 1$ above fasting level, the plasma insulin response was enhanced by ASA ( $70 \pm 7$ vs. $52 \pm 7 \mathrm{mU} / 1$ ), whereas the plasma C-peptide response was identical. Despite higher insulin concentrations, glucose utilization was not significantly altered (control, $61 \pm$ 7; ASA, $65 \pm 6 \mu \mathrm{mol} \cdot \mathrm{kg}^{-1} \cdot \mathrm{min}^{-1}$ ) indicating impairment of tissue sensitivity to insulin by ASA. Inhibition of prostaglandin synthesis was not likely to be involved in the effect of ASA, since insulin response and glucose utilization were unchanged following treatment with indomethacin. In the euglycaemic insulin $\left(1 \mathrm{mU} \cdot \mathrm{kg}^{-1} \cdot \mathrm{min}^{-1}\right)$ clamp studies, glucose utilization was unaltered by ASA despite higher insulin concentrations achieved during constant insulin infusion (103 \pm
\end{abstract}

4 vs. $89 \pm 4 \mathrm{mU} / 1)$. In Type 2 diabetic patients, fasting hyperglycaemia $(10.6 \pm 1.1 \mathrm{mmol} / \mathrm{l})$ and hepatic glucose production $\left(15 \pm 2 \mu \mathrm{mol} \cdot \mathrm{kg}^{-1} \cdot \mathrm{min}^{-1}\right)$ fell upon ASA treatment $(8.6 \pm 0.7$ $\left.\mathrm{mmol} / 1 ; 13 \pm 1 \mu \mathrm{mol} \cdot \mathrm{kg}^{-1} \cdot \mathrm{min}^{-1}\right)$. During the hyperglycaemic clamp study, the plasma response of insulin, but not of Cpeptide, was enhanced by ASA, whereas tissue sensitivity to insulin was reduced by 30 percent. It is concluded that in healthy and Type 2 diabetic man, ASA impairs tissue sensitivity to the action of insulin. This effect is counterbalanced by an augmented plasma insulin response to glucose, which results from a reduced insulin clearance rate. In Type 2 diabetic patients, the reduction in hepatic glucose production may be responsible for the amelioration of hyperglycaemia following ASA treatment.

Key words: Acetyl-salicylic acid, indomethacin, glucose utilization, insulin sensitivity, insulin secretion, insulin clearance, hepatic glucose production, Type 2 diabetes.
Prostaglandins (PG) may be involved in glucose homeostasis and insulin secretion. It has, however, been reported that $\mathrm{PG}_{\mathrm{E}}$ may either inhibit or stimulate insulin secretion depending upon the experimental conditions used [1], and that alterations in glucose homeostasis as noted during $\mathrm{PG}_{2}{ }_{2}$ infusion may not be attributed to $\mathrm{PG}_{2} \mathrm{E}_{2}$ itself, but rather to concomitant catecholamine release [2]. Furthermore, different inhibitors of PG synthesis appear to have variable effects on carbohydrate tolerance [1]. Nevertheless, the rise in insulin concentration and the amelioration of hyperglycaemia observed in non-insulin-dependent (Type 2) diabetic patients during treatment with sodium salicylate [3] or acetyl-salicylic acid (ASA) [4] may be attributed to inhibition of PG synthesis by these substances. In healthy subjects a stimulatory action of ASA has been described for insulin secretion in response to intravenous glucose and arginine $[5,6]$. In contrast, other inhibitors of PG synthesis, such as indomethacin decrease $[7,8]$ or fail to affect insulin secretion [9]. As to tissue sensitivity to insulin, it has recently been demonstrated that ASA, apart from enhancing insulin secretion, impairs glucose metabolism, whereas ibuprofen fails to alter glucose disposal [5]. Against this contradictory background the present study was designed (1) to elucidate the various effects of ASA as the most widely used non-steroidal anti-inflammatory drug on insulin secretion, insulin clearance as well as glucose utilization, and (2) to define the mechanism by which ASA reduces hyperglycaemia in Type 2 diabetic man. The euglycaemic insulin and hyperglycaemic clamp techniques $[10,11]$ were used to quantitate these determinants of glucose homeostasis.

\section{Materials and methods}

\section{Healthy subjects}

Fourteen healthy volunteers ( 12 males, 2 females), ranging in age from 20-27 years (mean \pm SEM, $23 \pm 1$ years) participated in the study. Body mass index was $21.5 \pm 0.3 \mathrm{~kg} / \mathrm{m}^{2}$. No subject had a family history of diabetes or any previous history of liver, kidney or endocrine disease. All participants were asked to consume a weight-maintaining diet containing at least $250 \mathrm{~g}$ carbohydrate per day, and none of them was on any medication during the 8-week period preceding the study.

\section{Non-insulin-dependent diabetic patients}

Seven Type 2 diabetic patients, whose individual clinical data are given in Table 1, were also enrolled in the study. The known duration of their diabetes was 2 to 18 years. The mean fasting blood glucose 

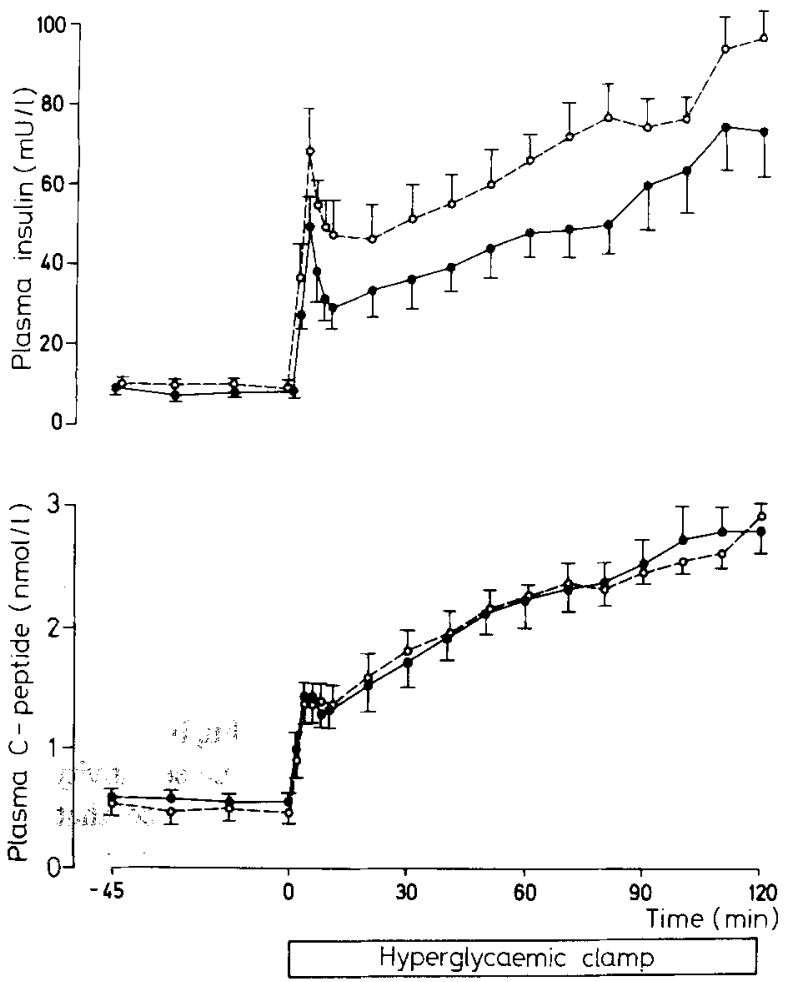

Fig. 1. Plasma concentrations of insulin and C-peptide in response to a square wave hyperglycaemic stimulus $(+7 \mathrm{mmol} / 1$ hyperglycaemic clamp study) with $\left(\mathrm{O}-\mathrm{O}^{-} \mathrm{O}\right)$ and without (ministration of acetyl-salicylic acid in healthy subjects. Mean \pm SEM is indicated

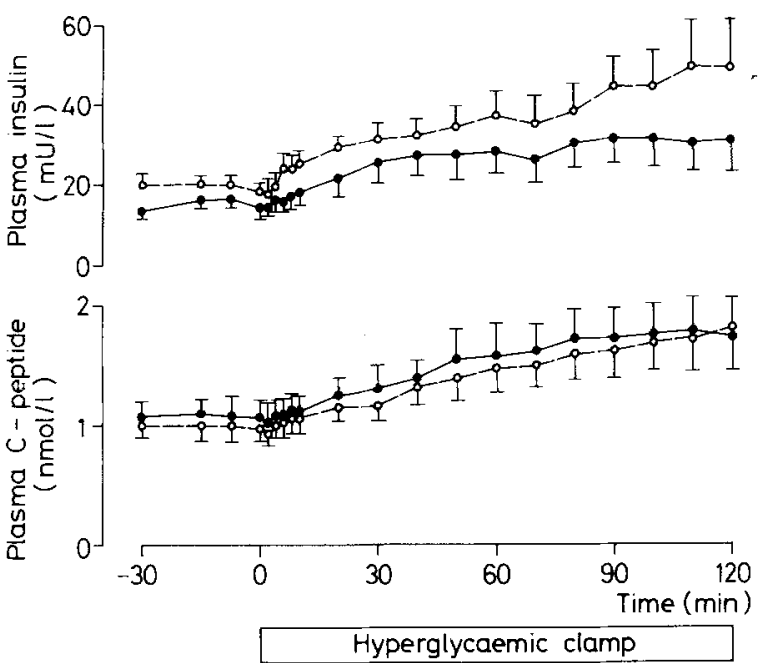

Fig. 2. Plasma concentrations of insulin and C-peptide in response to a square wave hyperglycaemic stimulus $(+7 \mathrm{mmol} / \mathrm{l})$ with $(\mathrm{O} \ldots \mathrm{-}-\mathrm{O})$ and without $(-0)$ preceding administration of acetyl-salicylic acid in Type 2 diabetic patients. Mean \pm SEM is indicated $(n=7)$

concentration obtained at 2 outpatient visits within the preceding 4 months was $9.4 \pm 0.6 \mathrm{mmol} / 1, \mathrm{HbA}_{1 \mathrm{c}} 6.7 \pm 0.5 \%$ (normal $\leqslant 5.8 \%$ ), urinary glucose loss was $2.9 \pm 1.8 \mathrm{~g}$ per day without ketonuria. The patients continued their usual diet containing 120-150 g carbohydrate per day. No patient was on any oral hypoglycaemic therapy.

The purpose and potential risks of the study were carefully explained to all subjects before obtaining their written consent to participate. The study protocol was approved by the Ethical Committee of the University Hospital.

\section{Protocol}

All tests were performed with the subjects in the recumbent position after an overnight fast starting between 0700 and 0800 hours. A polyethylene catheter was placed in a retrograde direction in a wrist vein for blood sampling, and that hand was kept in a heated box at $70^{\circ} \mathrm{C}$ to ensure arterialization of venous blood. Two types of studies were performed:

Hyperglycaemic ( $+7 \mathrm{mmol} / \mathrm{l}$ ) clamp. In eight healthy subjects the effect of ASA on insulin secretion and glucose metabolism was examined with the hyperglycaemic clamp technique $[10,11]$. The arterial plasma glucose concentration was acutely raised by $7 \mathrm{mmol} / 1$ $(125 \mathrm{mg} / \mathrm{dl})$ above basal with a priming dose of glucose given in a logarithmically falling fashion over $10 \mathrm{~min}$. Subsequently, plasma glucose was maintained at the desired level by determination of plasma glucose every $5 \mathrm{~min}$ and appropriate adjustment of a variable glucose infusion. Blood for insulin and C-peptide measurements was drawn at 2-min intervals for the first $10 \mathrm{~min}$ and every $10 \mathrm{~min}$ thereafter. Under these steady-state conditions of hyperglycaemic hyperinsulinaem$\mathrm{ia}$, the endogenous glucose production is assumed to be completely suppressed in healthy man [12] and the amount of glucose infused (corrected for urinary glucose losses) must therefore equal the rate of glucose taken up by the body. It thus serves as a measure of the body's response to endogenous insulin.

All eight healthy subjects underwent a hyperglycaemic clamp study without any pretreatment (control) and following ASA administration (Colfarit ${ }^{\circledR}$, Bayer-Pharma, Leverkusen, FRG; $1 \mathrm{~g}$ t.i.d. for 3 days, and $1 \mathrm{~g}$ one hour prior to the test). Six of these eight subjects also participated in a hyperglycaemic clamp study after pretreatment with another inhibitor of PG synthesis, indomethacin (Indocid, Merck Sharp \& Dohme, Haarlem, Netherlands; $50 \mathrm{mg}$ t.i.d. for 3 days, and $50 \mathrm{mg} 1 \mathrm{~h}$ prior to the test). The same six subjects also volunteered for another hyperglycaemic clamp, in which insulin was infused continously at a rate of $0.25 \mathrm{mU} \cdot \mathrm{kg}^{-1} \cdot \mathrm{min}^{-1}$ to match the plasma insulin concentrations achieved in the study performed after ASA treatment.

Seven Type 2 diabetic patients also underwent a hyperglycaemic clamp study in combination with tracer glucose kinetic analysis for estimating hepatic glucose production (HGP). To this end, ${ }^{3} \mathrm{H}-3$-glucose (Amersham International Ltd, UK) was administered in a $55 \mu \mathrm{Ci}$ bolus dose followed by a continuous infusion at a rate of $0.40 \mu \mathrm{Ci} / \mathrm{min}$. The infusion of tritiated glucose was begun $180 \mathrm{~min}$ prior to initiation of the clamp. Plasma ${ }^{3} \mathrm{H}$-glucose specific activity, which reached a plateau in all patients during the $30 \mathrm{~min}$ basal period prior to starting the clamp, was determined at 5-10 min intervals throughout the study. All patients were studied before and after ASA administration as described above for healthy subjects.

Euglycaemic insulin clamp: In six healthy subjects, a primed-continuous infusion of crystalline biosynthetic human insulin (Eli Lilly Co., Indianapolis, IN) at rates of 1.0 and $10.0 \mathrm{mU} \cdot \mathrm{kg}^{-1} \cdot \mathrm{min}^{-1}$ was administered to acutely raise and maintain the arterial plasma insulin concentration at approximately 100 and $>1000 \mathrm{mU} / 1$, respectively, for $120 \mathrm{~min}$. Plasma glucose was maintained at the basal level by a variable glucose infusion as described for the hyperglycaemic clamp study. Under these steady-state conditions of euglycaemic hyperinsulinaemia the amount of glucose infused plus the rate of residual HGP equals the rate of glucose uptake by the body. ${ }^{3} \mathrm{H}$-glucose was not employed in the studies in healthy subjects to estimate HGP. However, physiologically, HGP is almost completely suppressed by the hyperinsulinaemia achieved and glucose infusion rates therefore largely equal glucose utilization. Only in states of diminished suppression of HGP by insulin will glucose infusion rates underestimate glucose utilization. Low- and high-dose insulin clamp studies, which were performed 4 days apart, were repeated after at least 10 days thereafter following the same ASA regimen as in the hyperglycaemic clamp study.

\section{Analytical procedures}

The plasma glucose concentration was determined in duplicate on arterialized venous samples using the glucose oxidase method (Glucostat, Beckman Instruments Corp., Fullerton, Calif., USA). Tritiated 
Table 1. Clinical data of Type 2 diabetic patients

\begin{tabular}{|c|c|c|c|c|c|c|c|c|}
\hline Patients & Sex & $\begin{array}{l}\text { Age } \\
\text { (years) }\end{array}$ & $\begin{array}{l}\text { Body mass } \\
\text { index } \\
\left(\mathrm{kg} / \mathrm{m}^{2}\right)\end{array}$ & $\begin{array}{l}\mathrm{HbA}_{1 \mathrm{c}} \\
(\%)\end{array}$ & $\begin{array}{l}\text { Serum } \\
\text { creatinine } \\
(\mu \mathrm{mol} / 1)\end{array}$ & Medication & $\begin{array}{l}\text { Duration } \\
\text { of diabetes } \\
\text { (years) }\end{array}$ & $\begin{array}{l}\text { Blood } \\
\text { glucose }^{\mathrm{a}} \\
(\mathrm{mmol} / \mathrm{l})\end{array}$ \\
\hline 2. & $F$ & 55 & 25.4 & 5.8 & 62 & digitoxin & 2 & 7.3 \\
\hline 3. & $\mathrm{M}$ & 49 & 27.1 & 6.8 & 79 & - & 9 & 9.3 \\
\hline 4. & $\mathrm{M}$ & 52 & 25.9 & 6.2 & 97 & - & 5 & 7.7 \\
\hline 5. & $\mathrm{M}$ & 53 & 24.8 & 8.1 & 88 & - & 18 & 11.7 \\
\hline Mean & & 53 & 25.1 & 6.7 & 79 & & 8 & 9.4 \\
\hline$\pm \mathrm{SEM}$ & & 3 & 0.6 & 0.5 & 4 & & 2 & 0.6 \\
\hline
\end{tabular}

a Data of bood glucose represent the mean values obtained at the diabetic outpatient service on 2 occasions preceding the study by 4 months

Table 2. Plasma concentrations of glucose and insulin, as well as glucose infusion rate (M), insulin sensitivity (M/I ratio), and metabolic clearance rate of insulin $\left(\mathrm{MCR}_{\mathrm{l}}\right)$ during the hyperglycaemic $(n=8)$ and euglycaemic insulin clamp studies $(n=6)$ in healthy subjects $($ mean \pm SEM)

\begin{tabular}{|c|c|c|c|c|c|c|c|c|}
\hline & \multicolumn{2}{|c|}{ Glucose $(\mathrm{mmol} / \mathrm{l})$} & \multicolumn{3}{|c|}{ Insulin (mU/1) } & \multirow{2}{*}{$\begin{array}{l}\mathrm{M} \\
20-120 \mathrm{~min} \\
\left(\mu \mathrm{mol} \cdot \mathrm{kg}^{-1}\right. \\
\left.\min ^{-1}\right)\end{array}$} & \multirow{2}{*}{$\begin{array}{l}\mathrm{M} / \mathrm{I} \\
\left(\mu \mathrm{mol} \cdot \mathrm{kg}^{-1} \cdot\right. \\
\min ^{-1} \text { per } \mathrm{mU} / \\
1 \times 100)\end{array}$} & \multirow{2}{*}{$\frac{\mathrm{MCR}_{\mathrm{I}}}{\left(\mathrm{ml} \cdot \mathrm{kg}^{-1} \cdot\right.}$} \\
\hline & Basal & $\begin{array}{l}\text { Steady } \\
\text { state }\end{array}$ & Basal & Early & Late & & & \\
\hline \multicolumn{9}{|l|}{ Hyperglycaemic clamp } \\
\hline A. Control & $4.5 \pm 0.2$ & $11.4 \pm 0.1$ & $8 \pm 1$ & $35 \pm 5$ & $52 \pm 7$ & $61 \pm 7$ & $129 \pm 20$ & - \\
\hline B. + ASA & $4.5 \pm 0.1$ & $11.4 \pm 0.1$ & $10 \pm 1^{\mathrm{a}}$ & $51 \pm 8^{a}$ & $70 \pm 7^{b}$ & $65 \pm 6$ & $100 \pm 15^{a}$ & - \\
\hline \multicolumn{3}{|c|}{ Euglycaemic insulin clamp $\left(1.0 \mathrm{mU} \cdot \mathrm{kg}^{-1} \cdot \mathrm{min}^{-1}\right)$} & \multicolumn{4}{|c|}{ Steady state } & & \\
\hline A. Control & $5.2 \pm 0.1$ & $5.2 \pm 0.2$ & $13 \pm 2$ & & $89 \pm 4$ & $47 \pm 2$ & $55 \pm 4$ & $11.3 \pm 0.5$ \\
\hline B. + ASA & $5.2 \pm 0.4$ & $5.2 \pm 0.3$ & $14 \pm 1$ & & $03 \pm 4^{b}$ & $50 \pm 2$ & $48 \pm 3^{a}$ & $9.8 \pm 4^{b}$ \\
\hline \multicolumn{9}{|c|}{$\begin{array}{l}\text { Euglycaemic insulin clamp } \\
\left(10.0 \mathrm{mU} \cdot \mathrm{kg}^{-1} \cdot \min ^{-1}\right)\end{array}$} \\
\hline
\end{tabular}

${ }^{\mathrm{a}, \mathrm{b}}$ Indicates significant difference when compared with the respective control study $\left({ }^{\mathrm{a}} p<0.05,{ }^{\mathrm{b}} p<0.005\right)$

Table 3. Plasma concentrations, utilization (M) and hepatic production (HGP) of glucose during the hyperglycaemic clamp studies in Type 2 diabetic patients $(n=7$; mean \pm SEM $)$

\begin{tabular}{|c|c|c|c|c|c|c|c|}
\hline & \multicolumn{2}{|l|}{ Glucose } & $\begin{array}{l}\mathrm{M} \\
20-120 \mathrm{~min} \\
\left(\mu \mathrm{mol} \cdot \mathrm{kg}^{-1} .\right. \\
\left.\min ^{-1}\right)\end{array}$ & $\begin{array}{l}\mathrm{M} / \mathrm{I} \\
\left(\mu \mathrm{mol} \cdot \mathrm{kg}^{-1}\right. \\
\min ^{-1} \text { per } \mathrm{mU} / \\
1 \times 100)\end{array}$ & \multicolumn{3}{|l|}{ HGP } \\
\hline \multicolumn{8}{|c|}{ Hyperglycaemic clamp } \\
\hline A. Control & $10.6 \pm 1.1$ & $17.6 \pm 1.1$ & $26 \pm 3$ & $135 \pm 34$ & $15 \pm 2$ & $3 \pm 2$ & $5 \pm 3$ \\
\hline B. + ASA & $8.6 \pm 0.7^{a}$ & $15.9 \pm 0.7$ & $24 \pm 1$ & $84 \pm 21^{\mathrm{a}}$ & $13 \pm 1^{\mathrm{a}}$ & $2 \pm 1$ & $4 \pm 2$ \\
\hline
\end{tabular}

${ }^{a}$ Indicates significant difference when compared with the respective control study without ASA ( $\left.{ }^{a} p<0.05\right)$

glucose specific activity was determined by the Somogyi procedure [13] with glucose concentration in the Somogyi filtrates analyzed by the hexokinase reaction (Boehringer, Mannheim, FRG). Determination of plasma insulin and C-peptide were performed by radioimmunoassay (inter- and intraassay coefficient of variation $8 \%$ and $6 \%$ respectively) as previously described [14]. $\mathrm{HbA}_{1 \mathrm{c}}$ was determined by the microcolumn technique (Biorad, Richmond, CA). Salicylate was measured in plasma colorimetrically on an automatic clinical analyzer (ACA II, Du Pont, Genf, Switzerland) [15].

\section{Calculations}

During the clamp studies, the glucose infusion rate required to maintain the desired glucose level was determined by calculating the mean value observed from $20-120 \mathrm{~min}$. The total amount of glucose metab- olized (M) was then calculated by correcting for urinary glucose losses and for the, although minor, changes in plasma glucose (space correction) [10]. In the studies employing ${ }^{3} \mathrm{H}$-glucose kinetic analysis, HGP in the basal state was determined by dividing the tritiated glucose infusion rate by the steady-state plateau of glucose specific activity achieved during the $30 \mathrm{~min}$ preceding the clamp period. As a nonsteady-state condition in glucose specific activity exists after glucose infusion, the rate of glucose turnover was calculated by Steele's equations in their derivative form [16] using a total volume of distribution of $280 \mathrm{ml} / \mathrm{kg}$ body weight and a pool fraction of 0.65 [17]. The rate of HGP was calculated by subtracting the glucose infusion rate from the rate of glucose appearance as determined by the isotopic tracer technique. During the hyperglycaemic clamp studies, the early and late insulin response were determined by calculating the mean plasma insulin (I) and C-peptide concentrations during the 0 - to 10 -min and the 10 - to 120 -min periods. The $\mathrm{M} / \mathrm{I}$ ratio then provides a measure of the 
effectiveness of insulin on tissue glucose uptake. The metabolic clearance rate (MCR) of insulin was calculated by dividing the continuous insulin infusion rate by the mean increment in plasma insulin concentrations.

All data are presented as the mean \pm SEM. Statistical significance between means was calculated by the Student's paired two-tailed ttest.

\section{Results}

\section{Healthy subjects}

Fasting state. In the basal state, plasma concentrations were $4.8 \pm 0.2 \mathrm{mmol} / 1$ for glucose, $0.53 \pm 0.07 \mathrm{nmol} / 1$ for C-peptide, and $9.9 \pm 0.9 \mathrm{mU} / 1$ for insulin. After ASA treatment, which raised plasma salicylate concentration into the therapeutic range, $906 \pm 94 \mu \mathrm{mol} / 1$, plasma glucose $(4.8 \pm 0.2 \mathrm{mmol} / 1)$, and C-peptide $(0.50 \pm$ $0.10 \mathrm{nmol} / \mathrm{l})$ were unchanged, whereas insulin was increased slightly to $12.5 \pm 0.6 \mathrm{mU} / 1(p<0.02)$.

Hyperglycaemic clamp ( $+7 \mathrm{mmol} / \mathrm{l}$; Table 2). When plasma glucose was acutely raised and maintained at $11.4 \pm 0.1 \mathrm{mmol} / 1$ (coefficient of variation $4 \pm 1 \%$ ), a biphasic insulin response was observed. The early and late plasma insulin responses were $57 \pm 21 \%(p<0.05)$ and $45 \pm 13 \%(p<0.005)$, respectively, higher after ASA as compared to the intraindividual control study. However, plasma C-peptide responses in the control and ASA studies were identical (Fig. 1). Plasma insulin concentrations observed in the hyperglycaemic clamp studies with ASA were closely mimicked by the additional infusion of insulin $(70 \pm 7$ vs. $73 \pm 9 \mathrm{mU} / \mathrm{l})$. Pretreatment with indomethacin did not alter the plasma insulin response to the square wave stimulus of hyperglycaemia.

The amount of glucose metabolized by the entire body (M) was $61 \pm 7 \mu \mathrm{mol} \cdot \mathrm{kg}^{-1} \cdot \mathrm{min}^{-1}$ in the control study. This was not significantly altered by pretreatment with ASA, $65 \pm 6$, despite higher insulin concentrations. Tissue sensitivity to insulin, as calculated by the M/I ratio was therefore diminished by $21 \pm 4 \%$ by ASA $(p<0.005$; Table 2). In contrast, glucose utilization and insulin sensitivity were unaltered by the administration of indomethacin. In the hyperglycaemic clamp study, in which insulin concentrations observed following ASA administration were mimicked by i.v. insulin, glucose utilization was markedly increased $\left(90 \pm 9 \mu \mathrm{mol} \cdot \mathrm{kg}^{-1}\right.$. $\min ^{-1} ; p<0.005$ ), whereas insulin sensitivity remained unchanged as compared to the control study.

Euglycaemic insulin clamp $\left(1.0 \mathrm{mU} \cdot \mathrm{kg}^{-1} \cdot \mathrm{min}^{-1}\right.$; Table 2). As in the hyperglycaemic clamp studies, plasma glucose was kept close to the desired level, as demonstrated by a small coefficient of variation $(4 \pm 1 \%)$. Insulin infusion caused the hormone's plasma concentration to increase to $89 \pm 4 \mathrm{mU} / 1$ in the control study, and to $103 \pm 4 \mathrm{mU} / \mathrm{I}$ following ASA treatment $(p<$ 0.005 ). Thus, calculated MCR of insulin was reduced by $13 \pm 2 \%$ by ASA $(p<0.005)$. Glucose infusion rate (M) necessary to maintain euglycaemia was $47 \pm 2 \mu \mathrm{mol}$. $\mathrm{kg}^{-1} \cdot \min ^{-1}$ in the control, which was not different from the $50 \pm 2$ seen after ASA administration. Correcting for the higher insulin concentrations achieved following ASA by calculating an $\mathrm{M} / \mathrm{T}$ ratio, insulin sensitivity was reduced by ASA $(48 \pm 3$ vs. $55 \pm 4 \mu \mathrm{mol}$. $\mathrm{kg}^{-1} \cdot \min ^{-1}$ per $\left.\mathrm{mU} / 1 \times 100 ; p<0.05\right)$.

Euglycaemic insulin clamp $\left(10.0 \mathrm{mU} \cdot \mathrm{kg}^{-1} \cdot \mathrm{min}^{-1}\right.$; Table 2). Steady-state insulin concentrations obtained during the high-dose insulin infusion were higher after ASA, $1641 \pm 165$ vs. $1362 \pm 110 \mathrm{mU} / 1$ in the control study $(p<0.05)$, corresponding to a $19 \pm 4 \%$ decrease in MCR of insulin by ASA. Insulin-mediated glucose uptake without ASA, $69 \pm 3 \mu \mathrm{mol} \cdot \mathrm{kg}^{-1} \cdot \mathrm{min}^{-1}$, was identical after ASA treatment, $70 \pm 3$. Since glucose metabolism plateaus at insulin concentrations above $500 \mathrm{mU} / 1$ [18], the $\mathrm{M} / \mathrm{I}$ ratio, which assumes a linear relationship of these parameters, was not calculated.

\section{Type 2 diabetic patients}

Fasting state. Basal plasma concentrations were 10.6士 $1.1 \mathrm{mmol} / 1$ for glucose, $1.07 \pm 0.15 \mathrm{nmol} / 1$ for C-peptide, and $15 \pm 2 \mathrm{mU} / 1$ for insulin. Following ASA treatment, which raised plasma salicylate concentration to $728 \pm 100 \mu \mathrm{mol} / 1$, plasma glucose fell to $8.6 \pm 0.7$ $\mathrm{mmol} / 1(p<0.05)$, insulin was increased to $20 \pm 2 \mathrm{mU} / 1$ $(p<0.05)$, whereas plasma $C$-peptide remained essentially unchanged, $0.98 \pm 0.12 \mathrm{nmol} / \mathrm{l}$. Thus, the molar insulin/C-peptide ratio was augmented by ASA from $0.10 \pm 0.01$ to $0.14 \pm 0.01(p<0.005)$. Basal HGP, which at steady state conditions of fasting and negligible urinary glucose loss (mean, $0.1 \mu \mathrm{mol} \cdot \mathrm{kg}^{-1} \cdot \mathrm{min}^{-1}$ ) equals glucose utilization, fell from $15 \pm 2$ to $13 \pm 1 \mu \mathrm{mol}$. $\mathrm{kg}^{-1} \cdot \min ^{-1}$ upon ASA $(p<0.05$; Table 2$)$.

Hyperglycaemic clamp ( $+7 \mathrm{mmol} / \mathrm{l} ;$ Table 3$)$. When plasma glucose was acutely raised and maintained close to the desired level of $+7 \mathrm{mmol} / 1$ above fasting concentration (coefficient of variation $3 \pm 0.3 \%$ ), the response in plasma insulin was characterized by the absence of an early concentration peak within the first $10 \mathrm{~min}$ and the failure to significantly increase thereafter. In contrast to plasma insulin, which was augmented by about $40 \%$ by ASA administration, C-peptide concentrations were unchanged by ASA. Accordingly, the insulin/Cpeptide ratio was increased by ASA $(0.12 \pm 0.01$ vs. $0.18 \pm 0.01, p<0.01)$. Despite higher insulin concentrations, glucose utilization was unaltered by ASA ( $26 \pm 3$ vs $\left.24 \pm 1 \mu \mathrm{mol} \cdot \mathrm{kg}^{-1} \cdot \mathrm{min}^{-1}\right)$. Therefore, tissue sensitivity to the action of insulin was reduced by $30 \pm 9 \%(p<$ 0.05). Suppression of HGP by increasing hyperglycaemia was incomplete before $\left(4 \pm 2 \mu \mathrm{mol} \cdot \mathrm{kg}^{-1}\right.$. $\left.\min ^{-1}\right)$ and after ASA treatment $\left(3 \pm 1 \mu \mathrm{mol} \cdot \mathrm{kg}^{-1}\right.$. $\min ^{-1} ; t=20-120 \mathrm{~min}$ ).

\section{Discussion}

Several studies have demonstrated that salicylate and ASA increase basal [19] and stimulated insulin concentrations in normal subjects $[5,19]$ and in non-insulin-de- 
pendent diabetic patients $[3,4,20]$. In particular, the defective acute insulin response to intravenous glucose characteristic for Type 2 diabetic patients can partially be restored by the infusion of ASA [21]. Since in normal man treatment with other inhibitors of PG synthesis, such as ibuprofen [5] or indomethacin [7,8], is associated with unaltered or decreased insulin responsiveness to glucose, respectively, it may be assumed that the different effects of these drugs may be due to actions apart from inhibiting PG synthesis. As to experiments in vitro, sodium salicylate has been shown to augment glucose-induced insulin release by the isolated perfused rat pancreas [22], and by monolayer cultures of rat pancreatic cells [23], but not by hamster islets [24].

In the present study, plasma insulin concentrations in fasting healthy subjects were higher after a 3-day treatment course with ASA. Also the increase in the hormone's plasma concentration in response to a standardized square wave hyperglycaemic stimulus was about 50 percent higher after ASA administration. This applied to both, the early and late phases of insulin secretion. In contrast to plasma concentrations of insulin, those of C-peptide were almost identical in the fasting state as well as during the hyperglycaemic stimulus (Fig.1). Even though the early and late responses in insulin secretion to hyperglycaemia were characteristically reduced in Type 2 diabetic patients [25], the hormonal pattern of augmented insulin but unchanged C-peptide concentrations was comparable to that found in normal man. Thus, the behaviour of plasma C-peptide as a reflexion of insulin secretion [26] strongly suggests that the higher insulin concentrations seen after ASA treatment are not brought about by a change in basal and stimulated insulin secretion rate as commonly implied in the literature, but rather by a diminution of insulin clearance. To validate this assumption, euglycaemic insulin clamp studies were performed in healthy subjects with two different insulin doses $(1.0$ and $10.0 \mathrm{mU}$. $\left.\mathrm{kg}^{-1} \cdot \mathrm{min}^{-1}\right)$. Despite identical insulin infusion rates before and after ASA treatment, the plasma insulin concentrations achieved were consistently higher during the latter condition. Thus, the higher plasma insulin levels observed after ASA in the basal state and in response to glucose result from an ASA-induced reduction in unsulin removal. However, due to possible limitations in the interpretation of C-peptide as a measure of insulin secretion [27], an increase of the latter upon ASA cannot be completely ruled out. An effect on plasma insulin is not seen, when indomethacin or ibuprofen [5] is employed instead of ASA. Although a great deal of in-vitro data directly demonstrate that ASA along with other inhibitors of PG synthesis stimulate insulin secretion $[22,23]$, species differences may exist [24] and invitro experiments may not accurately reflect hormonal events in intact man. Several studies have demonstrated that salicylate or ASA lower plasma glucose in normal subjects [19] and Type 2 diabetic patients [3, 4]. Importantly, the improvement of glucose tolerance seems to depend upon continuing $\mathrm{B}$ cell function, and no im- provement in metabolic control becomes therefore apparent in insulin requiring diabetic patients [6]. In the present study glucose utilization in response to a square wave plateau of hyperglycaemia was unchanged by ASA in healthy as well as diabetic man. When, however, glucose utilization was corrected for the higher plasma insulin concentrations achieved, tissue sensitivity to the action of endogenously secreted insulin as calculated by the $\mathrm{M} / \mathrm{I}$ ratio was reduced by about $20-30$ percent. To validate this estimate of insulin sensitivity, further hyperglycaemic clamp studies were performed in healthy subjects with insulin concentrations strictly comparable to those seen in the ASA treated group by the additional infusion of exogenous insulin. Estimation of the necessary insulin infusion rate was made possible by our previous observation that exogenous insulin does not modify glucose-induced insulin secretory response, but simply adds to the plasma insulin response [28]. Using this approach, glucose utilization was markedly enhanced and thus calculated insulin sensitivity was normal. This line of reasoning not only confirms the inhibitory action of ASA on tissue sensitivity to insulin, but gives evidence for the validity of calculating an $\mathrm{M} / \mathrm{I}$ ratio for estimating tissue sensitivity to insulin. No such an effect on insulin sensitivity was found for other inhibitors of PG synthesis, such as for indomethacin given in a dose equipotent to ASA in regard to PG inhibition [29] or for ibuprofen in the study by Newman et al. [5]. Whether the effects of ASA treatment on insulin action are due to interference at binding or postreceptor sites remains to be established.

When in the euglycaemic insulin clamp studies plasma insulin was raised to concentrations within the still physiological range of $100 \mathrm{mU} / \mathrm{l}$, glucose utilization was not altered by ASA treatment. When, however, correction was applied for the higher insulin concentrations achieved after ASA by calculating the respective $\mathrm{M} / \mathrm{I}$ ratio, impaired effectiveness of insulin on tissue glucose uptake was unveiled. Since HGP, which also contributes to glucose input, was not determined in healthy subjects, glucose utilization may have been underestimated. However, HGP is known to almost completely suppress (95-100 percent) at these insulin concentrations [18]. Thus, only if ASA had reduced suppression of HGP, had glucose utilization and thus insulin sensitivity during ASA treatment been underestimated. This explanation, however, appears to be highly unlikely on the basis of the results from the hyperglycaemic clamp study and from the fact that, if at all, PG synthesis inhibitors attenuate HGP [30].

Our data also reconcile how salicylate possibly improves glucose tolerance in Type 2 diabetic patients [3, $4,21]$. It appears that impairment of tissue sensitivity to the action of insulin, which is characteristic for these patients [31], may even deteriorate further upon ASA treatment. This event, however, is counterbalanced by augmented circulating insulin concentrations due to a reduction in insulin clearance. The latter mechanism may help to explain the restraining effect of ASA on 
HGP. Reports of enhanced plasma insulin response to glucose stimulation by ASA in non-insulin-dependent diabetic patients $[3,4,21]$ are in support of this concept.

In conclusion, treatment with ASA impairs insulin action in healthy and in Type 2 diabetic man. Impaired glucose utilization is, however, counterbalanced by an augmented plasma insulin response to glucose, which results from a reduced clearance rate of insulin. In Type 2 diabetic patients a reduction in HGP due to greater insulin availability appears to be responsible for the blood glucose lowering effect of ASA treatment. Since no effects on glucose utilization and plasma insulin response to glucose are seen after treatment with other PG inhibitors, such as indomethacin or ibuprofen, the ASA induced metabolic and hormonal events may be regulated by PG independent mechanisms.

Acknowledgements. The authors wish to thank Mrs. A.Hofer, Mrs. A.Stockmayer, Mrs. I. Hofer, and Mr. K. Liener for technical assistance. The study was supported by a grant to W.W. of the "Fonds zur Förderung der wissenschaftlichen Forschung Österreichs", no. P 5164.

\section{References}

1. Robertson AP (1983) PGE, carbohydrate homeostasis, and insulin secretion. A suggested resolution of the controversy. Diabetes 32: 231-234

2. Newman WP, Brodows RG (1982) Metabolic effects of prostaglandin $\mathrm{E}_{2}$ infusion in man: possible adrenergic mediation. J Clin Endocrinol Metab 55: 496-501

3. Field JB, Boyle C, Remer A (1967) Effect of salicylate infusion on plasma-insulin and glucose tolerance in healthy persons and mild diabetics. Lancet 1: 1191-1194

4. Micossi P, Pontiroli AE, Baron SH, Tamayo RC, Lengel F, Bevilacqua M, Raggi U, Norbiato G, Foà PP (1978) Aspirin stimulates insulin and glucagon secretion and increases glucose tolerance in normal and diabetic subjects. Diabetes 27: 1196-1204

5. Newman WP, Brodows RG (1983) Aspirin causes tissue insensitivity to insulin in normal man. $\mathbf{J}$ Clin Endocrinol Metab 57: 1102-1106

6. Prince RL, Larkins RG, Alford FP (1981) The effect of acetylsalicylic acid on plasma glucose and the response of glucose regulatory hormones to intravenous glucose and arginine in insulin-treated diabetics and normal subjects. Metabolism 30:293-298

7. Widström A (1977) Influence of indomethacin on glucose-induced insulin response in normal man - role of prostaglandins in the rapid insulin release? Horm Metab Res 9: 172-175

8. Topol E, Brodows RG (1980) Effects of indomethacin on acute insulin release in man. Diabetes 29:379-382

9. Vierhapper H, Bratusch-Marrain P, Waldhäusl W (1980) Unchanged arginine-induced stimulation of insulin, glucagon, growth hormone and prolactin after pretreatment with indomethacin in normal man. J Clin Endocrinol Metab 50: 1131-1134

10. DeFronzo RA, Tobin J, Andres R (1979) Glucose clamp technique: a method for quantifying insulin secretion and resistance. Am J Physiol 237: E214-E 223

11. Bratusch-Marrain PR (1984) Die euglykämische Insulin- und hyperglykämische Clamp-Technik: Methoden zur Bestimmung der Insulinsensitivität der Gewebe und der Glukosesensitivität der BZelle. Infusionsther Klin Ernähr 11: 4-10

12. Wolfe RR, Allsop JR, Burke JF (1979) Glucose metabolism in man: responses to intravenous glucose infusion. Metabolism 28: $210-220$
13. Somogyi M (1930) A method for the precipitation of blood filtrates for the determination of sugar. J Biol Chem 86: 655-663

14. Waldhäusl W, Bratusch-Marrain P, Gasic S, Korn A, Nowotny P (1979) Insulin production rate following glucose ingestion estimated by splanchnic C-peptide output in normal man. Diabetologia 17: $221-227$

15. Natelson S (1957) Microtechniques of clinical chemistry for the routine laboratory. Thomas CC (ed). Springfield, III, p 332

16. Steele R (1959) Influence of glucose loading and of injected insulin on hepatic glucose output. Ann NY Acad Sci 82: 420-430

17. Bratusch-Marrain PR, Smith D, DeFronzo RA (1982) The effect of growth hormone on glucose metabolism and insulin secretion in man. J Clin Endocrinol Metab 55: 973-982

18. Rizza R, Mandarino L, Gerich J (1981) Dose-response characteristics for the effects of insulin on glucose production, glucose utilization and overall glucose metabolism in man: determination using sequential infusion of insulin in conjunction with the glucose clamp technique. Am J Physiol 240: E630-E639

19. Giugliano D, Torella R, Siniscalchi N, Impronta L, D'Onofrio F (1978) The effect of acetylsalicylic acid on insulin response to glucose and arginine in normal man. Diabetologia 14:359-362

20. Vierhapper $H$, Bratusch-Marrain $P$, Waldhäusl W, Nowotny $P$, Panzer S (1983) Increased secretion of insulin but unchanged secretion of growth hormone in hyperglycaemic type II diabetics treated with acetyl-salicylic acid. Clin Endocrinol 18: 613-620

21. Robertson RP (1981) Prostaglandins, glucose homeostasis and diabetes mellitus. Med Clin North Am 65: 759-771

22. Garcia J, Arata M, Fernández ME, Astolfi E, Basabe JC (1982) Salicylate intoxication and glucose-induced insulin secretion in the rat. Horm Metab Res 14: 553-554

23. Metz SA, Robertson RP, Fujimoto WY (1981) Inhibition of prostaglandin $\mathrm{E}$ synthesis augments glucose-induced insulin secretion in cultured pancreas. Diabetes 30: 551-557

24. Baron SH, Dunbar JC, Foà PP (1982) Lack of effect of acetylsalicylic acid on insulin secretion in isolated hamster islets. Horm Metab Res 14: 437-438

25. Bratusch-Marrain PR, Komjati M, Waldhäusl W (1985) Glucose metabolism in non-insulin-dependent diabetic patients with experimental hyperthyroidism. J Clin Endocrinol Metab 60: $1063-1068$

26. Bratusch-Marrain PR, Waldhäusl WK, Gasic S, Hofer A (1984) Hepatic disposal of biosynthetic human insulin and porcine Cpeptide in humans. Metabolism 33: 151-157

27. Polonsky KS, Rubenstein AH (1984) C-peptide as a measure of the secretion and hepatic extraction of insulin. Pitfalls and limitations. Diabetes 33: 486-494

28. Bratusch-Marrain PR, Waldhäusl WK (1985) Suppression of basal, but not of glucose-stimulated insulin secretion by human insulin in healthy and obese hyperinsulinaemic subjects. Metabolism 34: $188-193$

29. Vierhapper H, Jörg J, Waldhäusl W (1984) Effect of acetyl-salicylic acid and of indomethacin on diuresis in man: the role of cyclooxygenase inhibition. Clin Sci 67:579-583

30. Miller JD, Ganguli S, Sperling MA (1983) Prostaglandin synthesis inhibitors impair hepatic glucose production in response to glucagon and epinephrine stimulation. Diabetes 32: 439-444

31. DeFronzo RA, Simonson D, Ferrannini E (1982) Hepatic and peripheral insulin resistance: a common feature of type 2 (non-insulin-dependent) and type 1 (insulin-dependent) diabetes mellitus. Diabetologia 23: 313-319

Received: 20 March 1985

and in revised form: 15 July 1985

Dr. P. Bratusch-Marrain

Division of Clinical Endocrinology and Diabetes mellitus

I. Medizinische Universitätsklinik

Lazarettgasse 14

A- 1090 Vienna

Austria 